\title{
Colonization capacity and monitoring of the biocontrol agent Pseudomonas sp. IMBG163 on wheat roots
}

\author{
M. V. Kovalchuk, T. L. Lytvynenko, O. V. Kononuchenko, T. M. Voznyuk, \\ S. Yu. Rymar, V. V. Negrutska, N. O. Kozyrovska
}

Institute of Molecular Biology and Genetics of National Academy of Sciences of Ukraine 150 Zabolotnoho str., Kyiv, 03143, Ukraine

E. mail: Kozyr@imbg.org.ua

\begin{abstract}
The effect of Pseudomonas sp. IMBGl63 on wheat seedlings (Triticum aestivum $L$ cv. Katyusha) was studied. This strain has been marked with the gus reporter gene in order to examine a colonization pattern and to monitor its maintenance on the plant roots. The strain IMBG163 significantly enhanced all biometric parameters measured: dry weight, height of shoots, length of roots. Co-culture of IMBGI63 with the plant growth promoting bacterium Paenibacillus sp. IMBG156 did enhance the PGP effects. Detection of marked experimental bacterium on/into the plant have being performed with histochemical GUS assay and did not reveal the endophytic pattern of colonization. For monitoring of IMBGI63 in the rhizosphere, a culture-independent method, ARDRA, has been used. A combination of conventional and molecular technigues showed IMBGI63 to be effective and persistent colonizer of the wheat roots.
\end{abstract}

Introduction. Saprophytic pseudomonads are common root-colonizing bacteria that can improve plant growth or health. Efficient exploitation of these bacteria in agriculture requires knowledge of traits that enhance ecological performance in the rhizosphere. Current environmental criteria designed to improve crop and forest productivity, together with the development of a sustainable agriculture, and the intended reduction of the use of fertilizers and pesticides have produced an ongoing increase in scientific interest and practical use of the plant growth promoting bacteria and biocontrol agents as inocula [1]. These effects are due mostly to a non-infective interaction of root-associated bacteria with plants. However, in some cases, the use of bacteria in agriculture has no success expected, since the environment can appear to be different and hostile to some bacteria. Therefore, before the deliberate use of a beneficial bacterium as an inoculum,

(C)

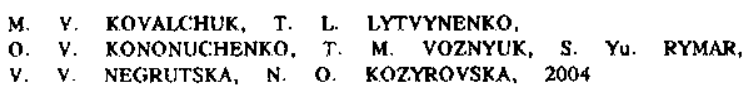

it is necessary to know some key parameters such as root colonization capacity, location, and degree of persistence of the inoculum [2]. The strain used in this work has already shown its antagonistic capacity [3].

Nevertheless, there is a paucity of data about conditions under which the inoculum strain has to compete with a wide variety of soil microorganisms. It is a well-established fact that Pseudomonas, being introduced into the microcosm, is able to enter into an unculturable state due to different reasons and cannot be cultivated by current techniques like the traditional agar plating [4, 5]. This limits the usefulness of colony counts. As a consequence, doubt has been raised that the results obtained seem not to be representative enough for the actual processes in nature.

On the other hand, there is an increasing concern about the risk of using this group of bacteria in the processes such as biological control since some species are pathogens and monitoring Pseudomonas is an 
essential element of inoculation programs $[6,7]$. Among the methods that have been suggested for monitoring bacteria in environmental samples are those based on usage of nucleic acids [8-10].

The aim of this work was to study the colonization capacity, persistence, and colonization pattern the wheat rhizosphere and endosphere of Pseudomonas sp. IMBG163, using both conventional and molecular methods.

Materials and Methods. The bacterial strains used in this study - Pseudomonas sp. IMBG163, Pseudomonas aureofaciens IMBG164, Klebsiella oxytoca IMBG26, Paenibacillus sp. IMBG156 - are deposited in the collection of Institute of Molecular Biology and Genetics of NASU, Pantoea agglomerans IMV56 was kindly provided by Prof. R. Gvozdyak. The strains were grown on nutrient broth medium LB [11], except Paenibacillus sp., that used minimal MZ medium [12]. Pseudomonas sp. IMBG163 was tested for production of indole acetic acid (IAA), using the method described in [13]. Siderophore production was detected by growing the culture on KB [14]. Phosphate solubilization capacity [15] was tested on KB supplemented with calcium phosphate. Plants were maintained under natural light in controlled conditions $\left(25 / 20^{\circ} \mathrm{C}, 14 / 10 \mathrm{~h}\right.$ light/dark,) in sand (a monoculture) and zeolite (Sokyrnytzya) (a bacterial assemblage) in a culture chamber of our design [16].

Ten wheat germinated seeds were inoculated by suspension of $10^{6}$ colony-forming units (CFU). At the end of the experiment ( 30 days after inoculation) all plants were harvested and the following data were collected: dry weight, height of shoots, length of roots. To estimate the external root colonization, root sections were vortexed in $0.9 \% \mathrm{NaCl}$, and serial dilutions were plated on LB and KB media supplemented with rifampicin $(50 \mu \mathrm{g} / \mathrm{ml})$ or streptomycin $(100 \mu \mathrm{g} / \mathrm{ml})$ when needed. To estimate the interior root colonization, root samples were surface disinfected with several incubations in Belizna (Kyiv) for 2 min alternated with rinsing in $0.9 \% \mathrm{NaCl}$ for 2 min; the surface disinfection parameters were optimized prior to the experimentation with control of surface contamination. The conjugation between bacteria was performed on LB agar medium plates, and the plasmid $p C A M 140$, conferring mTn5SsgusA20, was used as a vehicle of the gus gene [17]. Detection of bacteria on/into the plant and estimation of survival of experimental bacteria in the rhizosphere was performed with histochemical GUS assay [17]. DNA was isolated from the bacterial culture and plant tissues with kits from «MoBio Inc.» (USA). Pseudomonas-specific PCR amplifications were done as prescribed in [9]. $445 \mathrm{bp}$ amplicons of the 16S rDNA were cleaved with SalI («Fermentas», Lithuania).

The experimental scheme was repeated three times. Statistical analysis was performed using Sigma Plot 8.0 software. Standard deviations were calculated for each data point.

Results and Discussion. Metabolic capacity of Pseudomonas sp. IMBG163. The auxin production of strain was not detected after growth in LB medium, however, this strain was able to mobilize iron from chelating agents of medium $\mathrm{KB}$. The cleared halo of $2-3 \mathrm{~cm}$ has been observed around colonies. The strain was able also to solubilise calcium phosphate, forming the $2.5 \mathrm{~cm}$ halo around the colony. Although the mechanisms by which IMBG163 promotes plant growth are not yet fully understood, it is clear that this may be siderophore production and phosphate mobilizing that is in agreement with well established data [18].

Colonization capacity. Pseudomonads are often unable to establish population in significant number on plant roots, including wheat, and turn nonculturable [4, 19-21]. In this connection, Raaijmakers and Weller postulate that particular rhizobacterial genotypes have evolved a preference for colonization of specific crops [22]. Certain genotypes of pseudomonads well colonize wheat, including genetically modified strains, and establish high rhizosphere population densities up to $10^{7} \mathrm{CFU} / \mathrm{g}$ of root $[23-26]$. Our results show that strain IMBG163 is also able to colonize the wheat root, grown in mineral substrate of low bioavailability. There were no striking differences in the total number of CFU among different sampling times within a 30 day period, and the number of bacteria isolated from $1 \mathrm{~g}$ of fresh root was $(0.94-$ 1.3) $\cdot 10^{5}$ CFU. We did not also reveal a decrease in the population size or unculturable state of the strain when it was used as monoculture in aseptic conditions. Van Elsas et al. [8], studying the colonization of wheat roots by different strains of Pseudomonas, found that the highest number of bacteria was obtained 4 weeks after inoculation, decreasing afterwards.

In the wheat rhizosphere inoculated with the rationally assembled consortium of plant growth promoting rhizobacteria, the strain IMBG163 was quite competitive on the background of beneficial bacteria (fig. 1). It was not eliminated from the bacterial community in the plant rhizosphere. Moreover, the strain raised 20 -fold population being used in concert 


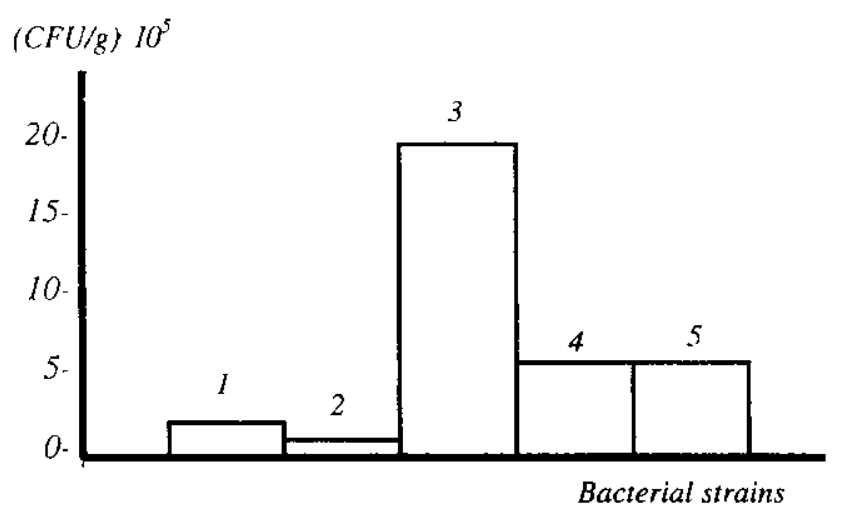

Fig. 1. Colonization capacity of Pseudomonas sp. IMBG163 as a member of bacterial assemblage in the wheat rhizosphere: 2 weeks after a planting ( $I-$ Klebsiella oxytoca; $2-$ Paenibacillus sp.; 3 Pseudomonas sp.; 4-Pantoea agglomerans; 5 -Pseudomonas aureofaciens)

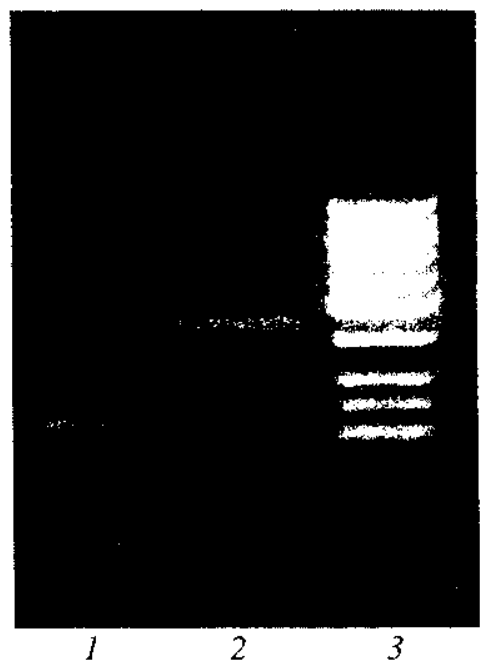

Fig. 2. Restriction pattern of the Pseudomonas sp. IMBG163 $16 \mathrm{~S}$ rDNA (455 bp): $1-S a l l$ fragments; $2-445$ bp fragment of $16 \mathrm{~S}$ rDNA; 3 - marker $(1031,900,800,700,600,500,400,300,250$, $200,150,100,50 \mathrm{bp}$, «Fermentas", Lithuania) with the mentioned bacteria. Our data exhibited high colonization capacity of Pseudomonas sp. IMBG163 in the wheat rhizosphere grown in soil of low bioavailability in contrast to the data of Hase et al. [4] and Bjorrklö et al. [21], who found that the inoculant strain on the roots of plants grown in the low fertility soil was mostly nonculturable cells.

We did not observe the endophytic colonization of wheat, although certain species of pseudomonads are known as endorhizosphere colonizers $[27-30]$. The bacterial cells entered into root hair, however, they did not spread in plant tissue.

Effects of the inoculated bacterium on the wheat growth. As shown in the table, the strain increased all the biometrical parameters measured, and this correlated with the earlier data [31]. Since the strain was shown to mobilize iron and phosphorus, the improved shoot growth could be the final result of improved nutrient uptake and plant nutrition.

The dual-culture assays in which two strains were grown in a liquid medium and later were used for the inoculation of wheat seeds showed that two unrelated bacteria could stimulate the wheat growth and biomass accumulation (table). This is in agreement with the recent data on interrelation of two unrelated Pseudomonas in the wheat rhizosphere [32]. Further experiments will show whether the bacteria due to this interpopulation communication in the rhizosphere stimulate each other in the expression of traits beneficial for plant growth or it is a cumulative effect of two bacteria.

In conclusion, these results show that the strain IMBG163 has good colonization capacity in the rhizosphere of wheat. However, it is necessary not only to provide the right bacterium, but also the correct techniques to check the fate of the inoculum in order

Biometrical data on effects of inoculation with plant growth promoting bacteria Pseudomonas sp. IMBGI63 on growth parameters of the 30-day wheat seedlings

\begin{tabular}{|c|c|c|c|}
\hline Varianı & Dry weight of a single plant, g & Shoot height, cm & Rool length, ctn \\
\hline Control & $0,035 \pm 0,002 a$ & $40,466 \pm 1,003 \mathrm{a}$ & $9,215 \pm 0,434 a$ \\
\hline Pseudomonas sp. IMBG 163 & $0,044 \pm 0,002 b$ & $44,316 \pm 1,036 \mathrm{~b}$ & $11,080 \pm 0,457 b$ \\
\hline Paenibacillus sp. IMBG 156 & $0,036 \pm 0,008 a$ & $44,856 \pm 1,212 b$ & $10,960 \pm 0,460 a$ \\
\hline $\begin{array}{l}\text { Pseudomonas sp. IMBG } 163 \text { and } \\
\text { Paenibacillus sp. IMBG } 156\end{array}$ & $0,045 \pm 0,003 b$ & $45,173 \pm 1,334 b$ & $11,665 \pm 0,689 b$ \\
\hline
\end{tabular}

$\mathrm{N}$ o $\mathrm{i}$ e. Error represents standard deviation. Treatment is different from the control at $\mathrm{p}=0.05$ as determined by Student's $t$-test. Values followed by the same letter in a column are not significantly different. 
to establish the most suitable way to use the microorganisms in agriculture.

Monitoring the strain was carried out by a culture-independent method in order to detect the bacterium in a case when it entered in unculturable state under some unfavorable conditions. We used a PCR method targeting $16 \mathrm{~S}$ ribosomal DNA for specific detection of Pseudomonas DNA in both plant and substratum DNA. A pair of primers, the universal 9-27 and specific for Pseudomonas DNA, PSM, creates amplicon of 445 bp [9]. The restriction enzyme Sall generates three fragments of around 75 , 120 and 250 bp specific for Pseudomonas sp. IMBG163 (fig. 2). Periodical samplings and amplifications showed presence of the bacterium DNA in total DNA isolated from the plant roots.

М. В. Ковальчук, Т. Л. Литвиненко, О. В. Кононученко, Т. М. Вознюк, С. Ю. Римар, В. В. Негруцька, Н. О. Козировська

Колонізаційна здатність та моніторинг біоконтролюючопо агента Pseudomonas sp. IMBG163 на коренях пшениці

Резюме

Вивчено вплив бактерії Pseudomonas sp. IMBGI63 на паростки пиениці (Triticum aestivum L., copm Катюша). Згаданий штам мітили репортерним gиs геном для дослідження способу колонізацї та моніторингу присутності бактерії на коренях рослини. ІІтам IMBGI63 значно збільшував усі вимірювані біометричні параметри: суху масу рослини, висоту пагонів та довжину коріння. При спільному культивуванні IMBGl63 бактерією, яка сприяе росту рослин (Paenibacillus sp. IMBGI56), спостерігається зростання ростстимулювальних ефектів. Детекцію міченої досліджуваної бактерії в/ на рослині проводили за допомогою гістохімічного аналізу, при иьому не виявлено ендофітного характеру колонізації. Для моніторингу IMBGJ63 у ризосфері піениці застосовували незалежну ві культияування бактерій методику ARDRA (рестрикційний аналіз ампліфікованої рДНК). Завдяки поєднанню традиційних i молекулярних методів доведено, що IMBGI63 ефективно та стабільно колонізуе корені пшениці.

М. В. Ковальчук, Т. Л. Литвиненко, О. В. Кононуценко,

T. Н. Вознюк, С. E. Рыммарь, В. В. Негруцкая,

H. A. Козыровская

Колонизационная способность и мониторинг

биоконтролирующего агента Pseudomonas sp. IMBG163

на корнях пшеницы

Резюме

Изучено влияние бактерии Pseudomonas sp. IMBGl63 на проростки пиеницы (Triticum aestivum, сорт Катюиа). Этот цтамм метили репортерньм gus сеном для исследования способа колонизации и мониторинга его присутствия на корнях растения. ШІтамм IMBGI63 значительно повышал все измеряемые биометрические параметры: сухую массу растения, высоту побегов и длину корней. При совместном культивировании IMBG163 с бактерией, способствующей росту растений (Paenibacillus sp. IMBGI56), наблюдается возрастание ростстимулирующих зффектов. Детекцию меченой исследо ванной бактерии в/на растении проводили с помощью систохимического анализа, при этом не обнаружено эндофитного характера колонизации Для мониторинга IMBGI63 в ризосфере пшеницы применяли не зависимый от культивирования бактерий метод ARDRA (рестрикционный анализ амплифицированной рДНК). Используя комбинацию традиционных и молекулярных методов доказано, что ІМВG163 эффективно и стабитьно колонизирует корни пшенцць.

\section{REFERENCES}

1. Montesinos $E$. Development, registration and commercialization of microbial pesticides for plant protection // Int. Microbiol. $-2003 .-6 .-$ P. 245-252.

2. Wiehe $W$., Hoflich $G$. Establishment of plant growth promoting bacteria in the rhizosphere of subsequent plants after harvest of the inoculated precrops // Microbiol. Res. -1995. - 150.P. 331-336.

3. Kovalchuk M. V., Negrutska V. V., Zaetz I. E., Pasechnik I. A., Gvozdyak R. I, Kozyrovska N. O. Ecologically-friendly crop production with microbial inoculants. II. Biocontroi capacity of bacterial isolates, candidates for inoculant development // Int. Conf. Natural Ecosystems of the Carpathian Mountains Under Conditions of Intensive Anthropogenic Impact (October 4-7, 2001, Uzhhorod, Ukraine).-Uzhhorod, 2001.-P. 82-85.

4. Hase C., Hottinger M., Moenne-Loccoz Y. Survival and cell culturability of biocontrol Pseudomonas fluorescens $\mathrm{CHAO}$ in the rhizosphere of cucumber grown in two soils of contrasting fertility status // Biol. and Fert. Soils. - 2000.-32.-P. $217-$ 221.

5. Mascher F., Hase C., Moenne-Loccoz Y., Defago G. The viable-but-nonculturable state induced by abiotic stress in the biocontrol agent Pseudomonas fluorescens CHA0 does not promote strain persistence in soil // Appl. Environ. Microbiol. - 2000.-66.-P. $1662-1667$.

6. Lee K., Lim J. B., Yum J. H., Yong D., Chong Y., Kim J. M., Livermore $D$. $M$. blavı. 2 cassette-containing novel integrons in metallo- $\beta$-lactamase-producing Pseudomonas aeruginosa and Pseudomonas putida isolates disseminated in a Korean hospital // Antimicrob. Agents and Chemother. - 2002.-46.P. 1053-1058

7. Docquier J. D., Riccio M. L., Mugnaioli C., Luzzaro F., Endimiani A., Toniolo A., Amicosante G., Rossolini $G . M$. IMP-12, a new plasmid-encoded metallo- $\beta$-lactamase from a Pseudomonas putida clinical isolate // Antimicrob. Agents and Chemother.-2003.-47.-P. 1522-1528.

8. Van Elsas J. D., Duarte G. F., Rosado A. S., Smalla $K$ Microbiological and molecular biological methods for monitoring microbial inoculants and their effects in the soil environment // J. Microbiol. Meth.-1998.-32.-P. 133-154.

9. Johnsen K., Enger Q., Jacobsen C. S., Thirup L., Torsvik V. Quantitative selective PCR of $16 \mathrm{~S}$ ribosoma! DNA correlates well with selective agar plating in describing population dynamics of indigenous Pseudomonas spp. in soil hot spots // Appl. Environ. Microbiol.-1999.-65.-P. 1786-1788.

10. Rezzonico F., Moenne-Loccoz Y., Defago $G$. Effect of stress on the ability of a phlA-based quantitative competitive PCR assay to monitor biocontrol strain Pseudomonas fluorescens $\mathrm{CHAO} / /$ Appl. Environ. Microbiol.-2003.-69._-P. 686-690.

11. Miller J. H. Experiments in molecular genetics.-New York: Cold Spring Harbor Iab. press, 1972.-436 p.

12. Пат. України 22797А. Спосіб отримання біопрепарату / H О. Козировська, О. М. Громозова // Опубл. 21.04 .98 
13. Tang $Y$. M., Bonner $J$. The enzymatic Inactivation of indoleacetic acid. 1. Some characteristics of the enzyme contained in pea seedlings // Arch. Blochem.-1947.-13.P. $11-25$.

14. King $E$. $O$., Ward $M . K$, Raney $D$. $E$. Two simple media for the demonstration of pyocyanin and fluorescin // J. Lab. Clin. Med.-1954.-44.-P. 301-307.

15. Аристовская T. В., Владимирская М. Е., Голлербах М. М. Большой практикум по михробиологии / Под ред. Г. Л Селибера.-М.: Высш. шх., 1962.-490 с.

16. Kovalchuk M. V., Negrutska V. V., Kovtunovych G. L., Lar $O$ V., Korniichuk $O$. S., Rogutskyi I. S., Alpatov A. P., Kozyrovska $N$. O., Kordyum V. A. Modeling the pNARSLux transfer in the wheat rhizosphere under simulated microgravity // Kosmichna nauka i technologiya (Suppl.).-2003.-9, N 2.-P. 10 14 .

17. Wilson $K$. J., Sessitsch A., Corbo J. C., Jiller $K E_{\text {., }}$ Akkermans A. D. L.,Jefferson R. A. $\beta$-Glucuronidase (GUS) transports for ecological and genetic studies of rhizobia and other Gram-negative bacteria // Microbiology.-1995.141. -P. $1691-1705$.

18. Dobbelaere S., Vanderleyden J., Okon Y. Plant growthpromoting effects of diazotrophs in the rhizosphere // Crit. Revs Plant Sci.-2003.-22, N 2.-P. 107-149.

19. Troxler J., Zala M., Moenne-Loccoz Y., Keel C., Defago G. Predominance of nonculturable cells of the biocontrol strain Pseudomonas fluorescens CHAO in the surface horizon of large outdoor lysimeters // Appl. Environ. Microbiol._1997._63.P. 3776-3782.

20. Normander B., Hendriksen N. B., Nybroe O. Green fluorescent protein-marked Pseudomonas fluorescens: localization, viability, and activity in the natural barley rhizosphere // Appl. Environ. Microbiol. -1999.-65.-P. 4646-4651.

21. Björklöf K., Sen R., Jorgensen $K$. S. Maintenance and impacts of an inoculated mer/luc-tagged Pseudomonas fluorescens on microbial communities in birch rhizospheres developed on humus and peat // Microb. Ecol.-2003.-45.-P. 39-52.

22. Raaijmakers J. M., Weller $D$. M. Exploiting genotypic diversity of 2,4-diacetylphloroglucinol-producing Pseudomonas spp. characterization of superior root-colonizing $P$. fluorescens strain Q8r1-96 // Appl. Environ. Microbiol.-2001.-67.P. 2545-2554.

23. McSpadden-Gardener B. B., Schroeder K. L, Kalloger S. E., Raaijmakers $J$. M., Thomashow L. S., Weller D. M. Genotypic and phenotypic diversity of phlD-containing Pseudomonas strains isolated from the rhizosphere of wheat // Appl. Environ. Microbiol. -2000.-66.-P. 1939-1946.

24. Van Overbeek $L$. S. Van Veen J. A., Van Elsas J. D. Induced reporter gene activity, enhanced stress resistance, and competitive ability of a genetically modified Pseudomonas fluorescens strain released into a field plot planted with wheat // Appl. Environ. Microbiol.-1997.-63.-P. 1965-1973.

25. Glandorf D. C. M., Verheggen P., Jansen T., Jorritsma J.-W., Smit $E$., Leeflang $P$., Wernars $K$., Thomashow L. S., Laureijs E., Thomas-Oates J. E., Bakker P. A. H. M., van Loon L. C. Effect of genetically modified Pseudomonas putida WCS358r on the fungal rhizosphere microflora of field-grown wheat // Appl. Environ. Microbiol.-2001.-67.-P. 3371-3378.

26. Viebahn M., Glandorf D. C. M., Ouwens T. W. M., Smit E., Leeflang P., Wernars $K$., Thomashow $L$ S., van Loon $L$. ., Bakker P. A. H. M. Repeated introduction of genetically modified Pseudomonas putida WCS358r without intensified effects on the indigenous microflora of field-grown wheat // Appl. Environ. Microbiol.-2003.-69.-P. 3110-3118.

27. Benizni E., Schoeny A., Pichard C., Guckert A. External and internal colonization of maize by two Pseudomonas strains: enumeration by enzyme-linked immunosorbent assay (ELISA) // Curr. Microbiol.-1997.-34.-P. 297-302.

28. Quadt-Hallmann A., Benhamou N., Kloepper J. W. Bacterial endophytes in cotton: mechanisms of entering the plant // Can. J. Microbiol. $-1997 .-43 .-$ P. 577-582.

29. Garbeva P., Overbeek $L$ S., Vuurde J. W., Elsas J. D. Analysis of endophytic bacterial communities of potato by plating and denaturing gradient gel electrophoresis (DGGE) of 16S rDNA based PCR fragments // Microb. Ecol.-2001.41, N 4.-P. 369-383.

30. Reiter B., Pfeifer U., Schwab H., Sessitsch A. Response of endophytic bacterial communities in potato plants to infection with Erwinia carotovora subsp. atroseptica // Appl. Environ. Microbiol.-2002.-68, N 5.-P. 2261-2268

31. Van Peer $\boldsymbol{R}$., Schippers B. Plant growth responses to bacterization with selected Pseudomonos spp. starins and rhizosphere microbial development in hydroponic cultures $/ /$ Can. J. Microbiol.-1989.-35.-P. 456-463.

32. Maurhofer M., Baehler E., Notz R., Martinez V., Keel C. Cross talk between 2,4-diacetylphloroglucinol-producing biocontrol pseudomonads on wheat roots // Appl. Environ. Microbiol.-2004.-70.-P. 1990-1998. 